\title{
Studies on Antimicrobial, Antifungal and Antioxidant Properties of Rosemary: A Review
}

\author{
İbrahim Ertan Erkan ${ }^{1, a}$, Özlem Aras Aşci ${ }^{2, b, *}$ \\ ${ }^{1}$ Department of Agricultural Biotechnology, Faculty of Agriculture, Isparta University of Applied Sciences, 32000 Isparta, Turkey \\ ${ }^{2}$ Pharmacy Services Program, Gelendost Vocational School, Isparta University of Applied Sciences, 32900 Gelendost/ Isparta, Turkey
} *Corresponding author

A R T I C L E I N F A B S T R A C T

\begin{tabular}{l|l}
\hline Review Article & $\begin{array}{l}\text { Rosemary has played an important role from past to present and has antimicrobial, antifungal and } \\
\text { antioxidant properties. With these features, it is used in many sectors, especially food and pharmacy. } \\
\text { Rosemary essential oils have a positive effect on biological activity. In addition, this oil prevents } \\
\text { lipid oxidation on foods, providing a long and fresh shelf life. Due to the high antioxidant properties } \\
\text { of rosemary, it eliminates the harmful effect of reactive oxygen species. Since the main components } \\
\text { of rosemary such as 1,8-cineol, camphor, } \alpha \text {-pinene, carnosic acid, and carnosol are being } \\
\text { accepted : } 21 / 11 / 2020 \\
\text { antimicrobial and antifungal, it is effective against many pathogens. With this review, it is aimed to } \\
\text { provide comprehensive information on the biological activities of rosemary and its extracts to shed } \\
\text { light on future research. }\end{array}$ \\
Keywords: &
\end{tabular}

Rosemary

Antimicrobial

Antibacterial

Antifungal

Antioxidant

\section{Introduction}

Demand for plants rich in valuable secondary metabolites is increasing day by day. One of these herbs is rosemary. Rosemary (Rosmarinus officinalis L.) is a valuable essential oil and spice plant from the Lamiaceae family. According to the evidence found by anthropologists and archaeologists, rosemary, which was used in medicine, food, and cosmetics in Ancient Egypt, China, Mesopotamia, and India, still maintains its importance in these areas today (Luqman et al., 2007). $R$. officinalis were used especially as pharmacological purpose of different geographical areas. Peoples were looks remedy for a lot of kind diseases then began to use of rosemary plant as cure of various illness such as stomach ache (Girón et al., 1991; Vieira, 2012; Benarba, 2016), sick throat (Gaspar et al., 2002; Montesano et al., 2012), strengthen to memory (Perry et al., 1999; Vieira, 2012; Benarba, 2016). It was emphasized conducted study that rosemary has some beneficial effects on the nervous system works and lipid metabolism. (Pawłowska et al., 2020). There were around 150 different compounds identified in rosemary essential oil (REO). Some of major compounds of these essential oils were used as various prevent various diseases (Table 1) (Borges et al., 2019).
Rosemary is an evergreen plant with a developed root and stem system and a lot of branching. These branches frequently have needle-shaped and bright green leaves with very short stems, each about $3 \mathrm{~cm}$ long. There are glandular hairs that carry plenty of essential oil on the lower surface of the leaves. This plant, which has blue flowers towards the ends of the stem, has round, slippery and dark colored fruits (Baydar, 2019).

Among the rosemary species in the world, $R$. officinalis, $R$. erriocaly Mill., R. laxiflorus (de Noé) and $R$. lavandulaceus (de Noé) are the most common species. Although it is one of the most characteristic plants of the Mediterranean, it grows naturally in the countries neighboring the Mediterranean, especially on the coast and mountain slopes facing the coast. Only $R$. officinalis species grows naturally and is cultivated in Mediterranean countries. The Aegean and Mediterranean coastline in Turkey shows the spread up to $1000 \mathrm{~m}$ altitude. However, economically, it is mostly collected wild in Mersin and Adana provinces at altitudes of 100 to $250 \mathrm{~m}$ from the coast and mountain slopes facing the coast (Baydar, 2019).

The economically utilized parts of the rosemary plant are its leaves and flowers, and its leaves contain $0.3-2.5 \%$ essential oil. The most important essential oil components 
in rosemary plant are 1.8-cineol (15-30\%), camphor (5$25 \%)$, and borneol (10-20\%). These essential oils obtained from rosemary are especially valuable in perfumes, cosmetics and aromatherapy. Rosemary juice also has an antiseptic effect and accelerates blood circulation in the skin. For this reason, fresh or dried leaves of rosemary are also added to dishes to give flavor and taste (Baydar, 2019).

In addition to the essential oils that rosemary contains, it also contains many compounds such as caffeic acid, ursolic acid, rosmanol, rosmeridiphenol, which have antiinflammatory, anti-obesity, antispasmodic, antiproliferative, neuro protective, antidepressant, antimutagenic, anticancer, antimicrobial and antiviral effects, especially carnosic acid, rosmarinic acid, camphor, and carnosol (Figure 1) (Pariš et al., 1993; Cuvelier et al., 1996; Lemonica et al., 1996; Kosaka and Yokoi, 2003; Oluwatuyi et al., 2004; Ibarra et al., 2011; Machado et al., 2012; Elansary and Mahmoud, 2015). Due to its antioxidant effects, extracts from rosemary are also widely used as stabilizers and natural antioxidants, as they prevent oxidative degradation in foods containing oil and fat (Hall and Cuppett, 1993; Pokorny; 1997; Miladi et al., 2013). For instance through REOs, flavoured cheese shelf life were extended by refrain from lipid oxidation (Olmedo et al., 2013). Besides rosemary were provide that protect sulphited-lamb product long shelf life (Ortuño et al., 2015). Rosemary oils were also decreased heat stress negative effects in japanese quails (Ciftci et al., 2013). Consequently it is indicating that rosemary has great potential to ensure along food storage (Ojeda-Sana et al., 2013; Ribeiro-Santos et al., 2015).

In addition, due to its antioxidant compounds, there has been an increasing interest in rosemary related applications in the pharmaceutical industry in recent years (Kuhlmann and Röhl, 2006). REOs were indicated vigorous cytotoxicity against tumor cells (Bel-7402, SK-OV-3 and HO-8910) and importantly slowed down mitosis (Stojanović-Radić et al., 2010; Wang et al., 2012). In addition to the benefits of REO on human health, studies have shown that it can be an alternative to insecticide. Some of these are acaricidal (Martinez-Velazquez et al., 2011), insecticidal (Papachristos et al., 2004; Waliwitiya et al., 2009), larvicidal (Duarte et al., 2015), antiparasitic (Cabuk et al., 2003) effects.

Table 1. R. officinalis essential oils on biological activity.

\begin{tabular}{l|l}
\hline $\begin{array}{c}\text { Positive effect on biological } \\
\text { activity }\end{array}$ & \multicolumn{1}{c}{ References } \\
\hline Antioxidant & $\begin{array}{l}\text { Pérez et al., 2007; Bozin et al., 2007; Rašković et al., 2014; Takayama et al., 2016; } \\
\text { Lin et al., 2016; Mekonnen et al., 2016; Bajalan et al., 2017b; Borges et al., 2018 }\end{array}$ \\
\hline Prevent liver injury & Rašković et al., 2014 \\
\hline Anti-inflammatory effect & Juhás et al., 2009; Nam et al., 2014; Silva-Filho et al., 2014; Borges et al., 2019 \\
\hline Inhibiton of lipid peroxidation & Bozin et al., 2007; Takayama et al., 2016 \\
\hline Inhibition of mucosal injury & Takayama et al., 2016 \\
\hline Anti-depressive & Faria et al., 2011; Machado et al.,2013 \\
\hline Antialgic & Vilela et al., 2016; Takayama et al., 2016 \\
\hline Anticancer & Al-Sereiti et al., 1999; Wang et al., 2012 \\
\hline
\end{tabular}<smiles>CC(C)c1cc2c(c(O)c1O)C13CCCC(C)(C)[C@@H]1CC(O2)C3=O</smiles>

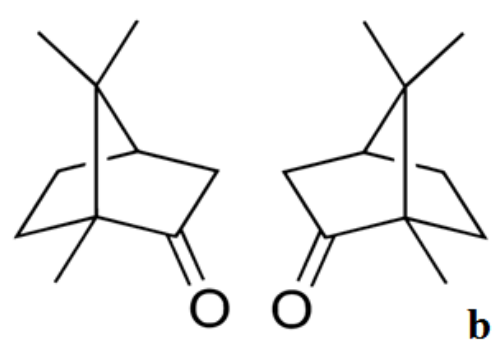

Figure 1. R. officinalis essential oil chemical structure a) carnosol b) camphor

\section{Antioxidant Activity of Rosemary Plants}

Medicinal plants contain valuable essential oils with antibacterial, antimicrobial, and antioxidant effects (Sevindik et al., 2017; Pehlivan and Sevindik, 2018; Sevindik et al., 2018; Pehlivan et al., 2018; Mohammed et al., 2019; Sevindik, 2019). Antioxidants are important to our daily life to reduce detrimental effects to reactive oxygen species, which can appear to results of exercise or rhythm of the life. A free radical is generally described as a molecule consists of unpaired electrons. There is not completely known that natural antioxidant defense system adequately resist the rising free radicals (Clarkson and Thompson, 2000). Thus it is important to understand emerge antioxidant activity as a result of some beneficial plants. Rosemary is type of plants that has antioxidant activity to protect cells from detrimental free radicals (Rašković et al., 2014). The research conducted by different group signify that essential oil from various populations were evaluated to DPPH radical inhibition assay, displayed relatively good antioxidant capacity (Wang et al., 2008; Zaouali et al., 2010; Rašković et al., 2014; Bajalan et al., 2017b).

Perez and research groups were expressed that when dry rosemary leaf exposed to radiation, antioxidant activity generally enhanced according to unapplied samples. Gamma radiated dry leaf antioxidant activities were changed to depend on extracts, methanol extracts didn't show any important change while ethanol and water extracts improve activity substantially. However, methanol 
based extracts demonstrated a superior antioxidant activity and higher phenolic content whether subject to gamma radiation or not. It was also clearly expressed that extraction solvent play main role to total phenolic content and antioxidant activity (Pérez et al., 2007).

Medicinal-Aromatic plants have acquired antifungal, antibacterial and antioxidant properties thanks to their secondary metabolites (Adrar et al., 2016; Bajalan et al., 2017a). Rašković and friends stated that REO antioxidant activities were noticed to reproduced partly from existence of phenolic groups. REO has free radical scavenging activity which has potential alleviate liver injury (ViudaMartos et al., 2010; Rašković et al., 2014). REO has also anti-inflammatory effect, moreover block of AAmetabolites nascency and barrier to $\mathrm{NF}-\kappa \mathrm{B}$ transcription which inhibition may provide contribution impact on antiinflammatory effects. Reactive oxygen species were responsible for noxious effect of inflammation. Which were alleviated due to essential oil high antioxidant activity (Arulselvan et al., 2016; Borges et al., 2019).

Investigation conducted by different group were clearly stated that lipid peroxidation importantly inhibited by antioxidant activity of REO (Bozin et al., 2007; Takayama et al., 2016). Rosemary salinity stress were reduced some essential oils such as $\alpha$-pinene, $\beta$-pinene. Although there was strong increase in verbenone, linalool, camphor, borneol, under salts stress. Salicylic acid was reduced harmful salt stress effect and enhanced to total phenolic, proline. Researches were signify that salicylic acid probably activate antioxidant enzymatic mechanism as well as enhance non-enzymatic antioxidants In same investigation quantitative real-time PCR were used for APX and various SOD genes expression which show higher expression level in salicylic acid applicated plants under salt stress (El-Esawi et al., 2017).

The studies about rosemary tissue culture which were conducted by Coskun (2019) and research group express that melatonin induced seconder metabolite content as elicitor. Another investigations were also determined that antioxidant enzymes become functional with phytomelatonin application (Li et al., 2012). Besides increase to mitochondrial electron transport chain performance, melatonin were played substantial role as defending plants against oxidative damages (Martinez et al., 2018). Interesting investigation by using tissue culture technic rosmarinic acid and total phenolic content stimulated through Pseudomonas using the as elicitor (Yang et al., 1997).

\section{Antibacterial-Antimicrobial Activity of Rosemary Plants}

In recent years, the use of medicinal aromatic plants has increased significantly in the food, pharmaceutical, and agricultural industries. In particular, rosemary extracts have been reported to exhibit strong antibacterial properties due to their chemical composition. Abdallah et al. (2019) reported that rosemary extract has strong antibacterial activity against the Xoo of GZ 0005 strain, which is the pathogen of rice bacterial blight. In several studies applying rosemary extract, it has been reported that gram (+) bacteria are more sensitive than negative ones (Pintore et al., 2002; Abu-Shanab et al., 2005).

Many studies have been conducted with extracts extracted from various plants to determine antimicrobial activity. In one of these, Abu-Shanab et al. (2004) founded that 3.125 and $1.5 \mathrm{mg} / \mathrm{mL}$ dose of rosemary extract was effective on $B$. subtilis and $S$. aureus gram positive bacteria. In a study conducted, it was shown that the oilbased formulations of rosemary have highly effective antimicrobial properties on colistin-resistant Klebsiella pneumonia clinical isolates (Abozahra et al., 2020). Baratta et al. (1998) showed significant activity against 7 of the 25 bacterial species used in the study.

It was found by Erdoğrul (2002) that rosemary has an antibacterial effect with ethyl acetate, methanol, and chloroform extracts Bacillus brevis FMC 3, Bacillus megaterium DSM 32, B. subtilis IMG 22, B. subtilis var. niger ATCC 10, Micrococcus luteus LA 2971, Mycobacterium smegmatus RUT, E. coli DM, Listeria monocytogenes SCOTT A, Staphylococcus aureus ATCC 25923, Streptococcus thermophilus, Pseudomonas fluorescens, and Yersinia enterocolitica O:3 P 41797. Thanks to the chemical compounds of the rosemary plant, its inhibitory effect on many different types of bacteria continue to be investigated.

It has been reported that the antimicrobial effect of REOs on bacterial species varies depending on the regions, season and months, but is quite high. The use of REOs was been found to give very good results against every bacterial strain (Celiktas et al., 2007; Gachkar et al., 2007). Bosnic et al. (2006) investigated the antibacterial properties of REO against gram (-) and (+) bacteria and reported that the most resistant microorganism was $P$. aeruginosa $(11.5 \mathrm{~mm})$ strain and the most sensitive was $B$. subtilis $(23.0 \mathrm{~mm})$. This was because they attributed it to the main component of thymol in rosemary. Bouyahya et al. (2017) examined REOs and their antibacterial, anti-leishmania, and antioxidant activities. GC / MS analysis of its essential oil detected 29 components, mainly oxygenated monoterpenes (63.743\%) and hydrocarbon monoterpenes $(21.231 \%)$. Its antibacterial activity was tested against ten pathogenic strains, and the susceptibility of Listeria monocytogenes, B. subtilis and E. coli strains of these was considerably higher than the commercialized antibiotic. Bajalan et al. (2017b), in their research using REO, found that it created an inhibition zone against mainly E. coli (18.51 mm), S. aureus (14.58 mm), $S$. agalactiae $(13.12 \mathrm{~mm})$, and $K$. pneumoniae $(13.97 \mathrm{~mm})$ bacteria, respectively. In a study investigating the changes in REOs under salinity stress, it was found that while the amount of linalool, camphor, borneol, and verbenone increased, it caused a decrease in $\alpha$-pinene, $\beta$-pinene, and cineol. In the same study, it was determined that the antibacterial effect of REO obtained from stressed plants leaves was higher than antibiotics (El-Sawi et al., 2017).

In a study comparing the antimicrobial activity of rosemary extracts with grapevine leaf extracts, it was found that rosemary extracts showed better inhibition against gram positive (S. aureus, B. cereus, L. monocytogenes) and gram negative bacteria ( $C$. jejuni, $S$. infantis, $E$. coli). Stronger antibacterial activity was determined especially against gram positive bacteria and $C$. jejuni (Abramovič et al., 2012). Bernardes et al. (2010) determined the ethanolic extracts of rosemary on Streptococcus mutans, $S$. salivarius, $S$. sobrinus, $S$. mitis, $S$. sanguinis and Enterococcus faecalis bacteria by liquid microdilution method. Accordingly, they determined that rosemary extract has antimicrobial activity against oral pathogens and this is caused by carnosic acid and carnosol (Table 2). 
Table 2. R. officinalis major components and type of against pathogen (Gram negative bacteria (G), Gram positive bacteria (G+), Fungal species (F))

\begin{tabular}{|c|c|c|}
\hline Major components & Type of pathogen against & References \\
\hline $\begin{array}{l}\text { 1,8-cineole }(13 \%) ; \alpha \text {-pinene }(19.60 \%) \text {; Camphor } \\
(12.60 \%) ; \alpha \text {-terpineol }(12.20 \%)\end{array}$ & $\begin{array}{l}\text { (G+) Micrococcus luteus, Staphylococcus aureus, }(\mathrm{G}- \\
\text { ) Acinetobacter calcoaceticus, Beneckea natriegens, } \\
\text { Citrobacter freundii, Erwinia carotovora, } \\
\text { Lactobacillus plantarum; }(F) \text { Aspergillus niger }\end{array}$ & Baratta et al., 1998 \\
\hline $\begin{array}{l}\text { 1,8-cineol (31.12\%); Camphor (30.12\%); } \alpha- \\
\text { pinene (18.18\%) }\end{array}$ & $\begin{array}{c}\text { (G+) Streptococcus Pyogenes; (G-) Acinetobacter } \\
\text { lwoffi, Shigella flexneri }\end{array}$ & Mangena and Muyima, 1999 \\
\hline $\begin{array}{c}\text { Camphor (22.20\%); 1,8-cineole (22\%); Myrcene } \\
(15.20 \%)\end{array}$ & (F) Ascosphaera apis & Larrán et al., 2001 \\
\hline $\begin{array}{c}\text { Bornyl acetate }(11.30-17 \%) ; 1,8 \text {-cineole (3.50- } \\
11.3 \%) ; \alpha \text {-pinene }(13.70-24.60 \%) \text {; Verbenone } \\
(4.40-24.90 \%)\end{array}$ & $\begin{array}{l}\text { (G-) Escherichia coli, Pseudomonas aeruginosa; (G+) } \\
\text { Staphylococcus aureus, ;Staphylococcus epidermidis }\end{array}$ & Pintore et al., 2002 \\
\hline $\begin{array}{c}\text { 1,8-cineol (18.03-22.23\%); Camphor (17.88- } \\
\text { 24.57\%); } \alpha \text {-pinene (7.07-70.60\%); Verbenone } \\
(1.50-16.00 \%)\end{array}$ & $\begin{array}{l}\text { (G+) B. subtilis, S. aureus; (G-) E. coli, P. aeruginosa; } \\
\text { (F) C. albicans, A. niger }\end{array}$ & $\begin{array}{l}\text { Abu-Shanab et al.; 2004; Santoyo et } \\
\text { al., 2005; Bosnic et al. } 2006\end{array}$ \\
\hline $\begin{array}{c}\text { Limonene (21.70\%); } \alpha \text {-pinene }(13.50 \%) ; \\
\text { Camphor (21.60\%); Z-linalool oxide }(10.80 \%)\end{array}$ & (F) C. albicans, Trichophyton tonsurans, T. rubrum & Bozin et al., 2007 \\
\hline $\begin{array}{l}\text { 1,8-cineole (12.10-61.40\%); Camphor (5.80- } \\
\text { 24.10\%); } \alpha \text {-pinene 0.40-14.20\%) }\end{array}$ & $\begin{array}{c}\text { (G+) S. aureus, Enterococcus feacalis,; S. } \\
\text { epidermidis, B. subtilis; (G-) E. coli, Proteus vulgaris, } \\
\text { Pseudomonas aureginosa, Klebsiella pneumonia; }(\mathrm{F}) \\
\text { C. albicans }\end{array}$ & Celiktas et al., 2007 \\
\hline $\begin{array}{c}\alpha \text {-pinene }(14.90 \%) ; 1,8 \text {-cineole }(7.43 \%) \text {; Linalool } \\
(14.90 \%)\end{array}$ & $\begin{array}{c}\text { (G+) Brevibacillus brevis, B. megaterium, B. subtilis, } \\
\text { B.subtilis var. niger, S. aureus, Mycobacterium } \\
\text { smegmatis, L. monocytogenes, S. thermophiles; (G-) } \\
\text { E. coli, P. fluorescens, Y. enterocolitica }\end{array}$ & Erdoğrul, 2002; Gachkar et al., 2007 \\
\hline $\begin{array}{c}\text { Isocarnosol (19.77-65.55\%); } \\
\text { Dihydronormorphinone }(3.36-14.34 \%) \\
\text { Verbenone }(2.442-13.02 \%)\end{array}$ & $\begin{array}{c}\text { (G+) S. aureus, Bacillus cereus; (G-) E. coli, } \\
\text { Pseudomonas aeruginosa }\end{array}$ & Genena et al., 2008 \\
\hline - & $\begin{array}{c}\text { (G+) S. aureus, S. epidermidis, Streptococcus mutants, } \\
\text { Mycobactcrium smegmalis }\end{array}$ & Luqman et al., 2007 \\
\hline Carnosic acid; Carnosol; Rosmarinic acid & $\begin{array}{l}\text { (G+) Streptococcus mutans, S. salivarius, S. sobrinus, } \\
\text { S. mitis, S. sanguinis, Enterococcus faecalis }\end{array}$ & Bernardes et al., 2010 \\
\hline $\begin{array}{c}\text { 1,8-cineol (38.50\%) Camphor (17.10\%); } \alpha \text {-pinene } \\
(12.30 \%) \text { Limonene (6.23\%) Camphene (6.00\%); } \\
\text { Linalool (5.70\%) }\end{array}$ & $\begin{array}{c}\text { (G+) Staphylococcus aureus, Bacillus cereus, B. } \\
\text { subtilis, Bacillus pumilis; (G-) Salmonella poona, E. } \\
\text { coli, Pseudomonas aeruginosa }\end{array}$ & Hussain et al., 2010 \\
\hline Carnosic acid & $\begin{array}{c}\text { (G+) S. aureus, B. cereus, L. monocytogenes; (G-) C. } \\
\text { jejuni, S infantis, E. coli }\end{array}$ & Abramovič et al., 2012 \\
\hline- & (G+) Bacillus cereus, Micrococcus luteus, S. aureus & Chan et al., 2012 \\
\hline $\begin{array}{c}\alpha \text {-pinene }(21.50 \%) ; 1,8 \text {-cineol } 15.20 \%) \text {; Borneol } \\
\text { (8.60\%); Verbenone }(8.60 \%)\end{array}$ & $\begin{array}{l}\text { (G+) S. aureus } S . \text { intermedius } S \text {. hyicus } S . \text { epidermidis } \\
\text { S. saprophyticus, } S \text {. aureus ssp. anaerobious, } S \text {. } \\
\text { capare } S \text {. gallinarum } S \text {. arlettae } S \text {. lentus } S . \text { equorum } \\
\text { S. simulans } S \text {. delphini } S \text {. chromogenes }\end{array}$ & Issabeagloo et al., 2012 \\
\hline $\begin{array}{c}\text { 1,8-cineol (13.66-49.05\%); Camphor (12.62- } \\
\text { 19.20\%); } \alpha \text {-pinene (10.08-21.03\%); Camphene } \\
(4.09-9.15 \%)\end{array}$ & $\begin{array}{l}\text { (G+) S. epidermidis, S. aureus, B. subtilis; (G-) } \\
\text { Pseudomonas aeruginosa, E.coli,; Proteus vulgaris } \\
\text { (F) C. albicans, A. niger }\end{array}$ & $\begin{array}{l}\text { Fu et al., 2007; Wang et al., 2012; } \\
\text { Matsuzaki et al., } 2013\end{array}$ \\
\hline $\begin{array}{c}\text { 1,8-cineol (46.40\%); Camphor (11.40\%); } \alpha \text { - } \\
\text { pinene (11\%); } \beta \text {-pinene (9.20\%); Camphene } \\
(5.20 \%)\end{array}$ & (G+) B. subtilis, S. aureus; (G-) E.coli, P. aeruginosa & $\begin{array}{l}\text { Sienkiewicz et al., 2013; Ghaedi et } \\
\text { al., } 2015\end{array}$ \\
\hline$\alpha$-pinene (50.80\%); 1,8-Cineole (24.40\%) & $\begin{array}{l}\text { (G+) Staphylococcus epidermis; (G-) Pseudomonas } \\
\text { aeruginosa, ;(F) Aspergillus spp., Trichophyton spp }\end{array}$ & Mekonnen et al., 2016 \\
\hline $\begin{array}{c}\text { 1,8-cineole (5.63-6.89\%); Camphor (1.66- } \\
\text { 4.82\%); } \alpha \text {-pinene }(14.69-0.81 \%)\end{array}$ & $\begin{array}{c}(\mathrm{G}+) \text { S. aureus,S. agalactiae,; } \\
\text { pneumonae }\end{array}$ & Bajalan et al., 2017b \\
\hline $\begin{array}{c}\alpha \text {-pinene (14.08\%); } 1,8 \text {-cineole }(23.67 \%) ; \\
\text { Camphor }(18.74 \%)\end{array}$ & $(\mathrm{G}+)$ Listeria monocytogenes, B. subtilis; (G-) E. coli & $\begin{array}{l}\text { Gouveia et al., 2016, Bouyahya et al., } \\
2017\end{array}$ \\
\hline $\begin{array}{l}\text { Linalool (5.43\%); Camphor (16.24); Borneol } \\
\text { (15.90\%); Verbenone (16.25\%) } \\
-\end{array}$ & $\begin{array}{l}\text { (G+) L. monocytogenes, } \text { S. aureus, } B \text {. cereus, } M \text {. } \\
\text { flavus; (G-) P. aeruginosa, E. coli } \\
\text { (G-) Xanthomonas oryzae }\end{array}$ & $\begin{array}{l}\text { El-Esawi et al., } 2017 \\
\text { Abdallah et al., } 2019 \\
\end{array}$ \\
\hline $\begin{array}{l}\text { Eucalyptol (48.72\%); Camphor (11.72\%); } \alpha \text { - } \\
\text { pinene (9.86\%); } \beta \text {-pinene }(8.35 \%)\end{array}$ & $\begin{array}{c}\text { (G+) S. aureus, B. subtilis; (G-) E. coli, K. } \\
\text { pneumoniae }\end{array}$ & $\begin{array}{l}\text { Stojanović-Radić et al., 2010; Park et } \\
\text { al., 2019; Risaliti et al., 2019; } \\
\text { Abozahra et al., } 2020\end{array}$ \\
\hline $\begin{array}{c}1,8-\operatorname{cineol}(31.12 \%) ; \text { Camphor }(12.04 \%) ; \alpha- \\
\text { pinene }(47.31 \%)\end{array}$ & (G+) Vagococcus salmoninarum & Metin and Biçer, 2020 \\
\hline $\begin{array}{c}\text { Camphor (32.50\%); 1,8-cineol (13.60\%); } \alpha- \\
\text { pinene }(9.80 \%)\end{array}$ & $\begin{array}{c}(\mathrm{G}+) \text { S. aureus, S. enteritidis; (G-) P. aeruginosa, E. } \\
\text { coli }\end{array}$ & Paulus et al., 2020 \\
\hline $\begin{array}{l}1,8 \text {-cineole }(52.20 \%) \text {; Camphor }(15.20 \%) ; \alpha- \\
\text { pinene }(12.40 \%)\end{array}$ & (F) Aspergillus flavus & Silva Bomfim et al., 2020 \\
\hline
\end{tabular}


Chan et al. (2012) compared dried and fresh samples of aromatic herbs such as rosemary, sage, thyme, basil, oregano, marjoram, peppermint, and spearmint in terms of antibacterial activity. While the plants used in the study did not show any effect against gram (-) bacteria, all of them showed antibacterial activity against gram $(+)$ ones. It has been reported that the plant that shows the highest antibacterial activity among them is fresh rosemary.

\section{Antifungal Activity of Rosemary Plants}

Increasing health problems due to various pathologies such as various cancers, liver diseases, and hormonal disorders caused by chemical residues in agricultural products brought the use of essential oils to the agenda for the development of natural and environmentally-friendly alternative fungicides (Carnesecchi et al., 2001; Rouabhi, 2010; Najar et al., 2020).

Silva Bomfim et al. (2020) evaluated the antifungal and antiaphylatoxigenic activity of REO against Aspergillus flavus with their study. They founded that, A. flavus reduced mycelial growth at a concentration of $250 \mu \mathrm{g} / \mathrm{mL}$ (15.3\%). In addition, it has been reported that ergosterol production and mycelium biomass decrease as the treatment concentration increases. Bozin et al. (2007) on the antifungal activity of REO on Trichophyton and Microsporum species for the first time in the literature stated that it was a highly effective agent against hydroxyl radicals and peroxidation processes of lipids. In addition, confirmed previously published data on its antibacterial and antifungal activity. Candida albicans is a polymorphic type of fungus that, under certain conditions, can cause infections ranging from skin infections to systemic infections that lead to death (Bozin et al., 2007; Celiktas et al., 2007; Mayer et al., 2013). There are studies showing that the essential oil of rosemary inhibits this type of fungus that causes many diseases in humans ( Fu et al., 2007; Akroum, 2020). It is reported that essential oil of rosemary has fungus inhibiting properties against Aspergillus niger which is an important disease factor in humans, plants, and animals (Table 2) (Santoyo et al., 2005; Fu et al., 2007; Türe et al., 2008; Zhao-ming, 2009; De Sousa et al., 2013).

As a result of in vitro studies, it was determined that it has antifungal activity. Larrán et al. (2001) found in their study that $800 \mu \mathrm{L} / \mathrm{L}$ dose of rosemary showed strong fungistatic activity against Ascosphaera apis which causes Chalkbrood disease in honey bees. Baratta et al. (1998) reported that rosemary is an effective inhibitor on Fusarium graminearum, however, Angioni et al. (2004) reported that it does not have an inhibitory effect and increases the growth of the fungus. Trichophyton spp. was determined to be inhibited by REO. It showed moderate activity against Aspergillus spp. (Table 2) (Mekonnen et al., 2016).

\section{Conclusions}

Some of the chemical components contained in the rosemary plant have many beneficial properties such as anticancer, anti-depressive and anti-inflammatory effects. REO has also been used for this purpose from ancient times until now a day. In this regard, current studies focus on the properties (antimicrobial, antifungal, and antioxidant) of rosemary that elicits on its pharmacological effects. Thanks to the new studies put forward, the potential for use as an alternative to harmful chemicals in the pharmaceutical industry has increased. REO by combating cytotoxic substances plays an important role in dealing with cancer. In addition REO was used many favorable treatments for detrimental diseases and also quite effective on antimicrobial usage.

It is seen that there were many investigations showing that rosemary extracts, which were also used in the food industry, provide the inhibition of lipid oxidation that will ensure the long-term preservation of fresh foods. Overall, past studies show us that, in the near future the harmless applications of rosemary will increase its widespread use in food, agriculture, cosmetics, dentistry, medicine and many more field.

\section{References}

Abramovič H, Terpinc P, Generalić I, Skroza D, Klančnik A, Katalinić V, Smole Možina S. 2012. Antioxidant and antimicrobial activity of extracts obtained from rosemary (Rosmarinus officinalis) and vine (Vitis vinifera) leaves. Croatian Journal of Food Science and Technology, 4: 1-8.

Abdallah Y, Ogunyemi, SO, Abdelazez A, Zhang M, Hong X, Chen J. 2019. The green synthesis of $\mathrm{MgO}$ nano-Flowers using Rosmarinus officinalis L.(Rosemary) and the antibacterial activities against Xanthomonas oryzae pv. oryzae. BioMed Research International, DOI: https://doi.org/10.1155/2019/5620989

Abozahra R, Abdelhamid SM, Wen MM, Abdelwahab I, Baraka K. 2020. A Nanoparticles based Microbiological Study on the Effect of Rosemary and Ginger Essential Oils against Klebsiella pneumoniae. The Open Microbiology Journal, 14(1). DOI: https//10.2174/1874285802014010205

Abu-Shanab, B, ADWAN GM, Abu-Safiya D, Jarrar N, Adwan K. 2004. Antibacterial activities of some plant extracts utilized in popular medicine in Palestine. Turkish Journal of Biology, 28: 99-102.

Adrar N, Oukil N, Bedjou F. 2016. Antioxidant and antibacterial activities of Thymus numidicus and Salvia officinalis essential oils alone or in combination. Industrial Crops and Products, 88: 112-119.

Akroum S. 2020. Antimicrobial activity of Rosmarinus officinalis and Zingiber officinale extracts on the species of the genus Candida and on Streptococcus pneumonia. Annales Pharmaceutiques Francaises, DOI: 10.1016/j.pharma.2020.06.003.

Al-Sereiti MR, Abu-Amer KM, Sena P. 1999. Pharmacology of rosemary (Rosmarinus officinalis Linn.) and its therapeutic potentials. Indian Journal of Experimental Biology, 37: 124130. http://hdl.handle.net/123456789/18973

Arulselvan P, Fard MT, Tan WS, Gothai S, Fakurazi S, Norhaizan ME, Kumar SS. 2016. Role of antioxidants and natural products in inflammation. Oxidative Medicine and Cellular Longevity. https://doi.org/10.1155/2016/5276130

Baratta MT, Dorman HD, Deans SG, Biondi DM, Ruberto G. 1998. Chemical composition, antimicrobial and antioxidative activity of laurel, sage, rosemary, oregano and coriander essential oils. Journal of Essential Oil Research, 10: 618-627.

Baydar H. 2019. Tibbi ve Aromatik Bitkiler Bilimi ve Teknolojisi (Genişletilmiş 6. Bask1). Süleyman Demirel Üniversitesi Yayınları. ISBN 978-975-7929-79-6.

Bajalan IZM, Goodarzi M, Darabi M. 2017a. Antioxidant activity and total phenolic and flavonoid content of the extract and chemical composition of the essential oil of Eremostachys laciniata collected from Zagros. Asian Pacific Journal of Tropical Biomedicine, 7: 144-146. 
Bajalan I, Rouzbahani R, Pirbalouti AG, Maggi F. 2017b. Antioxidant and antibacterial activities of the essential oils obtained from seven Iranian populations of Rosmarinus officinalis. Industrial Crops and Products, 107: 305-311

Benarba B. 2016. Medicinal plants used by traditional healers from South-west Algeria:an ethnobotanical study. Journal of of Intercultural Ethnopharmacology, 5:320. https://doi.org/10. 5455/jice.20160814115725

Bernardes WA, Lucarini R, Tozatti MG, Souza MG, Andrade Silva ML, da Silva Filho AA, Cunha WR. 2010. Antimicrobial activity of Rosmarinus officinalis against oral pathogens: relevance of carnosic acid and carnosol. Chemistry \& Biodiversity, 7: 1835-1840.

Borges RS, Lima ES, Keita H, Ferreira IM, Fernandes CP, Cruz RAS, Ferreira JV. 2018. Anti-inflammatory and antialgic actions of a nanoemulsion of Rosmarinus officinalis L. essential oil and a molecular docking study of its major chemical constituents. Inflammopharmacology, 26: 183-195.

Borges RS, Ortiz BLS, Pereira ACM, Keita H, Carvalho JCT. 2019. Rosmarinus officinalis essential oil: A review of its phytochemistry, anti-inflammatory activity, and mechanisms of action involved. Journal of Ethnopharmacology, 229: 2945.

Bouyahya A, Et-Touys A, Bakri Y, Talbaui A, Fellah H, Abrini J, Dakka N. 2017. Chemical composition of Mentha pulegium and Rosmarinus officinalis essential oils and their antileishmanial, antibacterial and antioxidant activities. Microbial Pathogenesis, 111: 41-49.

Bozin B, Mimica-Dukic N, Samojlik I, Jovin E. 2007. Antimicrobial and antioxidant properties of rosemary and sage (Rosmarinus officinalis L. and Salvia officinalis L. Lamiaceae) essential oils. Journal of Agricultural and Food Chemistry, 55: 7879-7885. https://doi.org/10.1021/jf0715323

Cabuk M, Alcicek A, Bozkurt M, Imre N. 2003. Antimicrobial properties of the essential oils isolated from aromatic plants and using possibility as alternative feed additives. In National Animal Nutrition Congress, September 2003, pp. 18-20.

Carnesecchi S, Schneider Y, Ceraline J, Duranton B, Gosse F, Seiler N, Raul F. 2001. Geraniol, a component of plant essential oils, inhibits growth and polyamine biosynthesis in human colon cancer cells. Journal of Pharmacology and Experimental Therapeutics, 298: 197-200.

Celiktas OY, Kocabas EH, Bedir E, Sukan FV, Ozek T, Baser KHC. 2007. Antimicrobial activities of methanol extracts and essential oils of Rosmarinus officinalis, depending on location and seasonal variations. Food Chemistry, 100: $553-$ 559.

Chan EW, Kong LQ, Yee KY, Chua WY, Loo TY. 2012. Rosemary and Sage Outperformed Six other Culinary Herbs in Antioxidant and Antibacterial PropertiesRosemary and Sage Outperformed Six other Culinary Herbs in Antioxidant and Antibacterial Properties. International Journal of Biotechnology for Wellness Industries, 1: 142-151.

Ciftci M, Şimşek ÜG, Azman MA, Cerci IH, Tonbak F. 2013. The effects of dietary rosemary (Rosmarinus officinalis L.) oil supplementation on performance, carcass traits and some blood parameters of Japanese quail under heat stressed condition. Kafkas Universitesi Veterinerlik Fakültesi Dergisi, 19: 595-599.

Clarkson PM, Thompson HS. 2000. Antioxidants: what role do they play in physical activity and health?. The American journal of clinical nutrition, 72: 637-646.

Coskun Y, Duran RE, Kilic S. 2019. Striking effects of melatonin on secondary metabolites produced by callus culture of rosemary (Rosmarinus officinalis L.). Plant Cell, Tissue and Organ Culture (PCTOC), 138: 89-95.

Cuvelier ME, Richard H, Berset C. 1996. Antioxidative activity and phenolic composition of pilot-plant and commercial extracts of sage and rosemary. Journal of the American Oil Chemists' Society, 73: 645-652.
De Sousa LL de Andrade SCA, Athayde AJAA, de Oliveira CEV, de Sales CV, Madruga MS, de Souza EL. 2013. Efficacy of Origanum vulgare L. and Rosmarinus officinalis L. essential oils in combination to control postharvest pathogenic Aspergilli and autochthonous mycoflora in Vitis labrusca L.(table grapes). International Journal of Food Microbiology, 165: 312-318.

Duarte JL, Amado JR, Oliveira AE, Cruz RA, Ferreira AM, Souto RN, Fernandes CP. 2015. Evaluation of larvicidal activity of a nanoemulsion of Rosmarinus officinalis essential oil. Revista Brasileira de Farmacognosia, 25: 189-192.

Elansary HO, Mahmoud EA. 2015. Egyptian herbal tea infusions' antioxidants and their antiproliferative and cytotoxic activities against cancer cells. Natural Product Research, 29: 474-479.

El-Esawi MA, Elansary HO, El-Shanhorey NA, Abdel-Hamid AM, Ali HM, Elshikh MS. 2017. Salicylic acid-regulated antioxidant mechanisms and gene expression enhance rosemary performance under saline conditions. Frontiers in Physiology, 8: 716.

Erdoğrul ÖT. 2002. Antibacterial activities of some plant extracts used in folk medicine. Pharmaceutical Biology, 40: 269-273.

Faria LRD, Lima CS, Perazzo FF, Carvalho JCT. 2011. Antiinflammatory and antinociceptive activities of the essential oil from Rosmarinus officinalis L. (Lamiaceae). International Journal of Pharmaceutical Sciences Review and Research, 7: $1-8$.

Fu Y, Zu Y, Chen L, Shi X, Wang Z, Sun S, Efferth T. 2007. Antimicrobial activity of clove and rosemary essential oils alone and in combination. Phytotherapy Research, 21: 989994.

Gachkar L, Yadegari D, Rezaei MB, Taghizadeh M, Astaneh SA, Rasooli I. 2007. Chemical and biological characteristics of Cuminum cyminum and Rosmarinus officinalis essential oils. Food Chemistry, 102: 898-904.

Gaspar N, Godinho J, Vasconcelos T, Caldas D, Mendes P, Barros O. 2002. Ethnobotany in the center of Portugal (Santarém). In Natural products in the new millennium: prospects and industrial application. Springer, Dordrecht. ISBN 978-90-481-6186-7.

Genena AK, Hense H, Smânia Junior A, Souza SMD. 2008. Rosemary (Rosmarinus officinalis): a study of the composition, antioxidant and antimicrobial activities of extracts obtained with supercritical carbon dioxide. Food Science and Technology, 28: 463-469.

Ghaedi M, Yousefinejad M, Safarpoor M, Khafri HZ, Purkait MK. 2015. Rosmarinus officinalis leaf extract mediated green synthesis of silver nanoparticles and investigation of its antimicrobial properties. Journal of Industrial and Engineering Chemistry, 31: 167-172.

Girón LM, Freire V, Alonzo A, Cáceres A. 1991. Ethnobotanical survey of the medicinal flora used by the Caribs of Guatemala. Journal of Ethnopharmacology, 34: 73-187.

Gouveia AR, Alves M, Silva JA, Saraiva C. 2016. The antimicrobial effect of rosemary and thyme essential oils against Listeria monocytogenes in sous vide cook-chill beef during storage. Procedia Food Science, 7: 173-176.

Hall C, Cuppett S. 1993. The effects of bleached and unbleached rosemary oleoresins on light-sensitized oxidation of soybean oil. Journal of the American Oil Chemists' Society, 70: 477482.

Hussain AI, Anwar F, Chatha SAS, Jabbar A, Mahboob S, Nigam PS. 2010. Rosmarinus officinalis essential oil: antiproliferative, antioxidant and antibacterial activities. Brazilian Journal of Microbiology, 41: 1070-1078.

Ibarra A, Cases J, Roller M, Chiralt-Boix A, Coussaert A, Ripoll C. 2011. Carnosic acid-rich rosemary (Rosmarinus officinalis L.) leaf extract limits weight gain and improves cholesterol levels and glycaemia in mice on a high-fat diet. British Journal of Nutrition, 106: 1182-1189. 
Issabeagloo E, Kermanizadeh P, Taghizadieh M, Forughi R. 2012. Antimicrobial effects of rosemary (Rosmarinus officinalis L.) essential oils against Staphylococcus spp. African Journal of Microbiology Research, 6: 5039-5042.

Juhás Š, Bukovská A, Čikoš Š, Czikková, S, Fabian D, Koppel J. 2009. Anti-inflammatory effects of Rosmarinus officinalis essential oil in mice. Acta Veterinaria Brno, 78: 121-127.

Kosaka K, Yokoi T. 2003. Carnosic acid, a component of rosemary (Rosmarinus officinalis L.), promotes synthesis of nerve growth factor in T98G human glioblastoma cells. Biological and Pharmaceutical Bulletin, 26: 1620-1622.

Kuhlmann A, Röhl C. 2006. Phenolic antioxidant compounds produced by in vitro. Cultures of Rosemary (Rosmarinus officinalis.) and their anti-inflammatory effect on lipopolysaccharide-activated microglia. Pharmaceutical Biology, 44: 401-410.

Larrán S, Ringuelet JA, Carranza MR, Henning CP, Ré MS, Cerimele EL, Urrutía MI. 2001. In vitro fungistatic effect of essential oils against Ascosphaera apis. Journal of Essential Oil Research, 13: 122-124.

Lemonica IP, Damasceno DC, Di-Stasi LC. 1996. Study of the embryotoxic effects of an extract of rosemary (Rosmarinus officinalis L.). Brazilian Journal of Medical and Biological Research, 29: 223-227.

Li C, Wang P, Wei Z, Liang D, Liu C, Yin L, Ma F. 2012. The mitigation effects of exogenous melatonin on salinityinduced stress in Malus hupehensis. Journal of Pineal Research, 53: 298-306.

Lin PC, Lee JJ, Chang IJ. 2016. Essential oils from Taiwan: Chemical composition and antibacterial activity against Escherichia coli. Journal of Food and Drug Analysis, 24: 464-470.

Luqman S, Dwivedi GR, Darokar MP, Kalra A, Khanuja SP. 2007. Potential of rosemary oil to be used in drug-resistant infections. Alternative Therapies in Health \& Medicine, 13: 54-59.

Machado DG, Cunha MP, Neis VB, Balen GO, Colla AR, Grando J, Prediger RD. 2012. Rosmarinus officinalis L. hydroalcoholic extract, similar to fluoxetine, reverses depressive-like behavior without altering learning deficit in olfactory bulbectomized mice. Journal of Ethnopharmacology, 143: 158-169.

Machado DG, Cunha MP, Neis VB, Balen GO, Colla A, Bettio LE, Pizzolatti MG. 2013. Antidepressant-like effects of fractions, essential oil, carnosol and betulinic acid isolated from Rosmarinus officinalis L. Food Chemistry, 136: 999 1005.

Mangena T, Muyima NYO. 1999. Comparative evaluation of the antimicrobial activities of essential oils of Artemisia afra, Pteronia incana and Rosmarinus officinalis on selected bacteria and yeast strains. Letters in Applied Microbiology, 28: 291-296.

Martinez V, Nieves-Cordones M, Lopez-Delacalle M, Rodenas R, Mestre TC, Garcia-Sanchez F, Rivero RM. 2018. Tolerance to stress combination in tomato plants: new insights in the protective role of melatonin. Molecules, 23: 535.

Martinez-Velazquez M, Rosario-Cruz R, Castillo-Herrera G, Flores-Fernandez JM, Alvarez AH, Lugo-Cervantes E. 2011. Acaricidal effect of essential oils from Lippia graveolens (Lamiales: Verbenaceae), Rosmarinus officinalis (Lamiales: Lamiaceae), and Allium sativum (Liliales: Liliaceae) against Rhipicephalus (Boophilus) microplus (Acari: Ixodidae). Journal of Medical Entomology, 48: 822-827.

Matsuzaki Y, Tsujisawa T, Nishihara T, Nakamura M, Kakinoki Y. 2013. Antifungal activity of chemotype essential oils from rosemary against Candida albicans. Open Journal of Stomatology, 3: 176-182.

Mayer FL, Wilson D, Hube B. 2013. Candida albicans pathogenicity mechanisms. Virulence, 4: 119-128.
Mekonnen A, Yitayew B, Tesema A, Taddese S. 2016. In vitro antimicrobial activity of essential oil of Thymus schimperi, Matricaria chamomilla, Eucalyptus globulus, and Rosmarinus officinalis. International Journal of Microbiology, 1-8 phttps://doi.org/10.1155/2016/9545693

Metin S, Biçer Zİ. 2020. Antibacterial activity of some essential oils againts Vagococcus salmoninarum. Su Ürünleri Dergisi, 37; 167-173.

Miladi H, Slama RB, Mili D, Zouari S, Bakhrouf A, Ammar E. 2013. Essential oil of Thymus vulgaris L. and Rosmarinus officinalis L.: Gas chromatography-mass spectrometry analysis, cytotoxicity and antioxidant properties and antibacterial activities against foodborne pathogens. Natural Science, 5: 729-739

Mohammed FS, Karakaş M, Akgül H, Sevindik M. 2019. Medicinal properties of Allium calocephalum collected from Gara Mountain (Iraq). Fresenius Environmental Bulletin, 28(10), 7419-7426.

Montesano V, Negro D, Sarli G, De Lisi A, Laghetti G, Hammer K. 2012. Notes about the uses of plants by one of the last healers in the Basilicata Region (South Italy). Journal of Ethnobiology and Ethnomedicine, 8: 15.

Najar B, Shortrede JE, Pistelli L, Buhagiar J. 2020. Chemical composition and in vitro cytotoxic screening of sixteen commercial essential oils on five cancer cell lines. Chemistry and Biodiversity, 17: e1900478.

Nam SY, Chung CK, Seo JH, Rah SY, Kim HM, Jeong HJ. 2014. The therapeutic efficacy of $\alpha$-pinene in an experimental mouse model of allergic rhinitis. International Immunopharmacology, 23: 273-282.

Ojeda-Sana AM, van Baren CM, Elechosa MA, Juárez MA, Moreno S. 2013. New insights into antibacterial and antioxidant activities of rosemary essential oils and their main components. Food Control, 31: 189-195.

Oluwatuyi M, Kaatz GW, Gibbons S. 2004. Antibacterial and resistance modifying activity of Rosmarinus officinalis. Phytochemistry, 65: 3249-3254.

Olmedo RH, Nepote V, Grosso NR. 2013. Preservation of sensory and chemical properties in flavoured cheese prepared with cream cheese base using oregano and rosemary essential oils. LWT-Food Science and Technology, 53: 409-417.

Ortuño J, Serrano R, Bañón S. 2015. Use of dietary rosemary diterpenes to extend the preservation of sulphited-lamb products. Small Ruminant Research, 123: 269-277.

Papachristos DP, Karamanoli KI, Stamopoulos DC, Menkissoglu-Spiroudi U. 2004. The relationship between the chemical composition of three essential oils and their insecticidal activity against Acanthoscelides obtectus (Say). Pest Management Science: Formerly Pesticide Science, 60: 514-520.

Pariš A, Štrukelj B, Renko M, Turk V, Pukl M, Umek A, Korant BD. 1993. Inhibitory effect of carnosolic acid on HIV-1 protease in cell-free assays. Journal of Natural Products, 56: 1426-1430.

Park J, Rho SJ, Kim YR. 2019. Enhancing antioxidant and antimicrobial activity of carnosic acid in rosemary (Rosmarinus officinalis L.) extract by complexation with cyclic glucans. Food Chemistry, 125119: 1-36. https://doi.org/10.1016/j.foodchem.2019.125119.

Paulus D, Luchesi LA, Busso C, Frata M, de Oliveira PJB. 2020. Chemical Composition, Antimicrobial and Antioxidant Activities of Essential Oils of Four Species of the Lamiaceae Family. European Journal of Medicinal Plants, 31: 129-140.

Pawłowska K, Janda K, Jakubczyk K. 2020. Properties and use of rosemary (Rosmarinus officinalis L.). Pomeranian Journal of Life Sciences, 66: 76-82.

Pehlivan M, Mohammed FS, Sevindik M, Akgul H. 2018. Antioxidant and oxidant potential of Rosa canina. Eurasian Journal of Forest Science, 6(4): 22-25. 
Pehlivan M, Sevindik M. 2018. Antioxidant and antimicrobial activities of Salvia multicaulis. Turkish Journal of Agriculture-Food Science and Technology, 6(5): 628-631.

Pérez MB, Calderon NL, Croci CA. 2007. Radiation-induced enhancement of antioxidant activity in extracts of rosemary (Rosmarinus officinalis L.). Food Chemistry, 104: 585-592.

Perry EK, Pickering AT, Wang WW, Houghton PJ, Perry NS. 1999. Medicinal plants and Alzheimer's disease: from ethnobotany to phytotherapy. Journal of Pharmacy and Pharmacology, 51: 527-534.

Pintore G, Usai M, Bradesi P, Juliano C, Boatto G, Tomi F, Chessa M, Cerri R, Casanova J. 2002. Chemical composition and antimicrobial activity of Rosmarinus officinalis L. oils from Sardinia and Corsica. Flavour and Fragrance Journal, 17: 15-19.

Pokorny J, Nguyen HT, Korczak J. 1997. Antioxidant activities of rosemary and sage extracts in sunflower oil. Nahrung (Weinheim), 41: 176-177.

Rašković A, Milanović I, Pavlović N, Ćebović T, Vukmirović S, Mikov M. 2014. Antioxidant activity of rosemary (Rosmarinus officinalis L.) essential oil and its hepatoprotective potential. BMC Complementary and Alternative Medicine, 14: 1-9.

Ribeiro-Santos R, Carvalho-Costa D, Cavaleiro C, Costa HS, Albuquerque TG, Castilho MC, Sanches-Silva A. 2015. A novel insight on an ancient aromatic plant: The rosemary (Rosmarinus officinalis L.). Trends in Food Science \& Technology, 45: 355-368.

Risaliti L, Kehagia A, Daoultzi E, Lazari D, Bergonzi MC, Vergkizi-Nikolakaki S, Bilia AR. 2019. Liposomes loaded with Salvia triloba and Rosmarinus officinalis essential oils: In vitro assessment of antioxidant, antiinflammatory and antibacterial activities. Journal of Drug Delivery Science and Technology, 51: 493-498.

Rouabhi R. 2010. Introduction and toxicology of fungicides. INTECH Open Access Publisher, Algeria, 364-382.

Santoyo S, Cavero S, Jaime L, Ibanez E, Senorans FJ, Reglero G. 2005. Chemical composition and antimicrobial activity of Rosmarinus officinalis L. essential oil obtained via supercritical fluid extraction. Journal of Food Protection, 68: 790-795.

Sevindik M, Akgul H, Pehlivan M, Selamoglu Z. 2017. Determination of therapeutic potential of Mentha longifolia ssp. longifolia. Fresen Environ Bull, 26(7): 4757-4763.

Sevindik M, Akgul H, Korkmaz AI, Sen I. 2018. Antioxidant Potantials of Helvella leucomelaena and Sarcosphaera coronaria. Journal of Bacteriology and Mycology Open Access, 6(2): 00173.

Sevindik M. 2019. Wild edible mushroom Cantharellus cibarius as a natural antioxidant food. Turkish Journal of AgricultureFood Science and Technology, 7(9): 1377-1381.

Sienkiewicz M, Łysakowska M, Pastuszka M, Bienias W, Kowalczyk E. 2013. The potential of use basil and rosemary essential oils as effective antibacterial agents. Molecules, 18: 9334-9351.

Silva-Filho SE, de Souza Silva-Comar FM, Wiirzler LAM, do Pinho RJ, Grespan R, Bersani-Amado CA, Cuman RKN. 2014. Effect of camphor on the behavior of leukocytes in vitro and in vivo in acute inflammatory response. Tropical Journal of Pharmaceutical Research, 13: 2031-2037.
Silva Bomfim N, Kohiyama CY, Nakasugi LP, Nerilo SB, Mossini SAG, Romoli JCZ, Machinski JrM. 2020. Antifungal and antiaflatoxigenic activity of rosemary essential oil (Rosmarinus officinalis L.) against Aspergillus flavus. Food Additives \& Contaminants: Part A, 37: 153-161.

Stojanović-Radić Z, Nešić M, Čomić L, Radulović N. 2010. Antimicrobial activity and cytotoxicity of commercial rosemary essential oil (Rosmarinus officinalis L.). Biologica Nyssana, 1: 83-88.

Takayama C, de-Faria FM, de Almeida ACA, Dunder RJ, Manzo LP, Socca EAR, Luiz-Ferreira A. 2016. Chemical composition of Rosmarinus officinalis essential oil and antioxidant action against gastric damage induced by absolute ethanol in the rat. Asian Pacific Journal of Tropical Biomedicine, 6: 677-681.

Türe H, Eroğlu E, Soyer F, Özen B. 2008. Antifungal activity of biopolymers containing natamycin and rosemary extract against Aspergillus niger and Penicillium roquefortii. International Journal of Food Science \& Technology, 43: 2026-2032.

Vieira VMDF. 2012. Etnobotânica de plantas medicinais comercializadas em mercados públicos do nordeste brasileiro. PhD Dissertation Universidade Federal do Ceará, Fortaleza, Brezilya.

Vilela J, Martins D, Monteiro-Silva F, González-Aguilar G, de Almeida JM, Saraiva C. 2016. Antimicrobial effect of essential oils of Laurus nobilis L. and Rosmarinus officinallis L. on shelf-life of minced "Maronesa" beef stored under different packaging conditions. Food Packaging and Shelf Life, 8: 71-80.

Viuda-Martos M, Ruiz Navajas Y, Sánchez Zapata E, FernándezLópez J, Pérez-Álvarez JA. 2010. Antioxidant activity of essential oils of five spice plants widely used in a Mediterranean diet. Flavour and Fragrance Journal, 25: 1319.

Waliwitiya R, Kennedy CJ, Lowenberger CA. 2009. Larvicidal and oviposition-altering activity of monoterpenoids, transanithole and rosemary oil to the yellow fever mosquito Aedes aegypti (Diptera: Culicidae). Pest Management Science: formerly Pesticide Science, 65: 241-248.

Wang W, Wu N, Zu YG, Fu YJ. 2008. Antioxidative activity of Rosmarinus officinalis L. essential oil compared to its main components. Food Chemistry, 108: 1019-1022.

Wang W, Li N, Luo M, Zu Y, Efferth T. 2012. Antibacterial activity and anticancer activity of Rosmarinus officinalis $\mathrm{L}$. essential oil compared to that of its main components. Molecules, 17: 2704-2713.

Yang R, Potter TP, Curtis OF, Sherry K. 1997. Tissue culturebased Selection of high rosmarinic acid producing clones of Rosemary (Rosmarinus officinalis L.) Using Pseudomonas Strain F. Food Biotechnology, 11: 73-88.

Zaouali Y, Bouzaine T, Boussaid M. 2010. Essential oils composition in two Rosmarinus officinalis L. varieties and incidence for antimicrobial and antioxidant activities. Food and Chemical Toxicology, 48: 3144-3152.

Zhao-ming LIU. 2009. Studies on the Chemical Components and Antimicrobial Activities of Volatile Oil from Rosmarinus officinalis L. Journal of Anhui Agricultural Sciences, 2. 